\section{A List of Germplasm Releases from the University of Wisconsin Table Beet Breeding Program, 1964-1992}

\author{
I.L. Goldman ${ }^{1}$ \\ Department of Horticulture, University of Wisconsin-Madison, 1575 Linden \\ Drive, Madison, WI 53706
}

The table beet (Beta vulgaris L.) breeding program at the Univ. of Wisconsin-Madison, initiated by W.H. Gabelman in 1949, was geared toward assessing the feasibility of $F_{1}$ hybrids. This attempt required an understanding of pollen sterility, inbreeding potential, and seed production characteristics. The primary breeding objectives of the beet program focused on sterile and maintainer lines for the production of hybrids, disease resistance, round to globe-shaped roots, improved color and sweetness, multigerm and monogerm seed, and enhancement of combining ability. Hybrids and inbred lines were released by Gabelman in cooperation with the Wisconsin State Agricultural Experiment Station during 1964-92.

Gabelman took advantage of useful genes found in sugar beet (also Beta vulgaris L.) in improving table beet germplasm. The sfallele, which conditions self-fertility, was introduced

Received for publication 31 July 1995 . Accepted for publication 28 Mar. 1996. The cost of publishing this paper was defrayed in part by the payment of page charges. Under postal regulations, this paper therefore must be hereby marked advertisement solely to indicate this fact.

${ }^{1}$ Assistant Professor of Horticulture. from a sugar beet breeding line obtained from V.F. and H. Savitsky, emigres from Russia working with F.V. Owen, U.S. Dept. of Agriculture-Agricultural Research Service, Fort Collins, Colo. The $s f$ allele allowed for inbreeding individual plants, a technique that was not previously possible in beet because of its self-incompatibility. Inbreeding enabled the development of more homogenous populations and ultimately resulted in uniform inbred lines. Similarly, the $x$ and $z$ alleles, conditioning sterility at the nuclear restorer locus (in homozygous recessive condition), were introduced from sugar beet breeding lines obtained from F.V. Owen. These alleles, in combination with the sterile cytoplasm obtained from Owen, allowed for the development of pollen-sterile breeding lines and their maintainer lines. The $B$ allele conditioning annual flowering habit also was obtained from sugar beet breeding material from V.F. Savitsky. The $B$ allele allowed for efficient development of sterile inbred lines since spring-sown plants carrying $B b$ flower in Madison, Wis., by midAugust. A cross of the constitution $S x x s f s f B b$ $\times N \_s f \_b b$ will give rise to $50 \%$ annual $(B b)$ progeny, which, because they are flowering, can be classified for sterility in the field. These annual sterile plants can then be decapitated, vernalized, and reflowered in winter in the greenhouse nursery, assuring continuous inbreeding of the sterile line with its maintainer line. The $m$ allele, which conditions the monogerm character, also was introduced into table beet via sugar beet germplasm obtained from V.F. Savitsky. The monogerm character has improved the precision of plant spacing, since each seed ball contains one seed that gives rise to only one seedling. The original sugar beet $x$ table beet crosses required $\approx 10$ generations of selection before commercially acceptable round, red roots were recovered.

The inbred lines released from Gabelman's program have been used in the production of hybrid beet seed throughout the world. In particular, the widespread distribution of sterile inbred lines has facilitated the development of hybrid beet in many countries. Many of the inbred lines released by Gabelman also have proved an important source of genes for highquality uniform beet roots for fresh market and processing.

Little description, other than that found in brief release notices, has been available for distribution to workers in the field of beet breeding and genetics. This report is an attempt to present a compilation of Gabelman's releases, including the year of release, line designation, salient features, and pedigree (Table 1). This report is one of a series that lists W.H. Gabelman's vegetable releases (Goldman, 1996a, 1996b).

\section{Literature Cited}

Goldman, I.L. 1996a. A list of germplasm releases from the University of Wisconsin onion breeding program, 1957-1993. HortScience 31:878879.

Goldman, I.L. 1996b. A list of germplasm releases from the University of Wisconsin carrot breeding program, 1964-1994. HortScience 31:882883.

Table 1. Year of release, name or number, description, and pedigree of table beet germplasm released by W.H. Gabelman, 1964-92.

\begin{tabular}{|c|c|c|}
\hline $\begin{array}{l}\text { Year of } \\
\text { release }\end{array}$ & $\begin{array}{l}\text { Name or } \\
\text { no. }\end{array}$ & Description $^{z}$ \\
\hline 1964 & $\mathrm{~W} 187 \mathrm{~A}^{\mathrm{y}}, \mathrm{W} 187 \mathrm{~B}^{\mathrm{x}}$ & Inbred, monogerm \\
\hline 1964 & W205 & $\begin{array}{l}\text { Inbred; excellent shape, smoothness, } \\
\text { crown size, and color; combines well for } \\
\text { quality characteristics with W187 }\end{array}$ \\
\hline 1964 & Pacemaker & $\begin{array}{l}\mathrm{F}_{1} \text { hybrid; monogerm; excellent shape, } \\
\text { smoothness, crown size, and color }\end{array}$ \\
\hline 1967 & W211A, W211B & $\begin{array}{l}\text { Inbred, good pollen producer, good } \\
\text { color, small crown }\end{array}$ \\
\hline 1972 & W218A, W218B & $\begin{array}{l}\text { Inbred, red-anthered sterile, good seed } \\
\text { producer, round smooth root, moderate } \\
\text { resistance to cercospora }\end{array}$ \\
\hline 1972 & W260A, W260B & $\begin{array}{l}\text { Inbred, brown-anthered sterile, } \\
\text { round smooth root }\end{array}$ \\
\hline 1972 & W279A, W279B & $\begin{array}{l}\text { Inbred, monogerm and multigerm, } \\
\text { moderate resistance to cercospora }\end{array}$ \\
\hline 1972 & $\mathrm{~W} 300 \mathrm{C}^{\mathrm{w}}$ & $\begin{array}{l}\text { Inbred, bolt resistant, round smooth root, } \\
\text { good pollinator, moderate resistance to } \\
\text { cercospora }\end{array}$ \\
\hline 1983 & Pacemaker 2 & $\begin{array}{l}\mathrm{F}_{1} \text { hybrid, excellent shape, smooth } \\
\text { exterior, excellent eating quality }\end{array}$ \\
\hline
\end{tabular}

\begin{abstract}
$\mathrm{W} 187 \mathrm{~B}$ is an $\mathrm{S}_{6}$-derived line from a cross of 'Perfected Detroit' and a source of the $m$ allele from V.F. and H. Savitsky. $\mathrm{W} 187 \mathrm{~A}$ is a $\mathrm{BC}_{3}$ derivative.

$\mathrm{S}_{4}$ derivative of a cross between'King

Red' and an unnamed breeding line
\end{abstract}

Pedigree

W187 x W205

Derived from a cross of 'Perfected Detroit' and 'King Red' with breeding lines

Derived from W162 ${ }^{\mathrm{w}}$ and 'Red Pak'

Derived from $\mathrm{W} 28^{\mathrm{v}}$ and $\mathrm{W} 163^{\mathrm{v}}$

Derived from 'Ruby Queen' and W187

Derived from 'Red Pak' and W163"

W218 x W279 
Table 1. Continued.

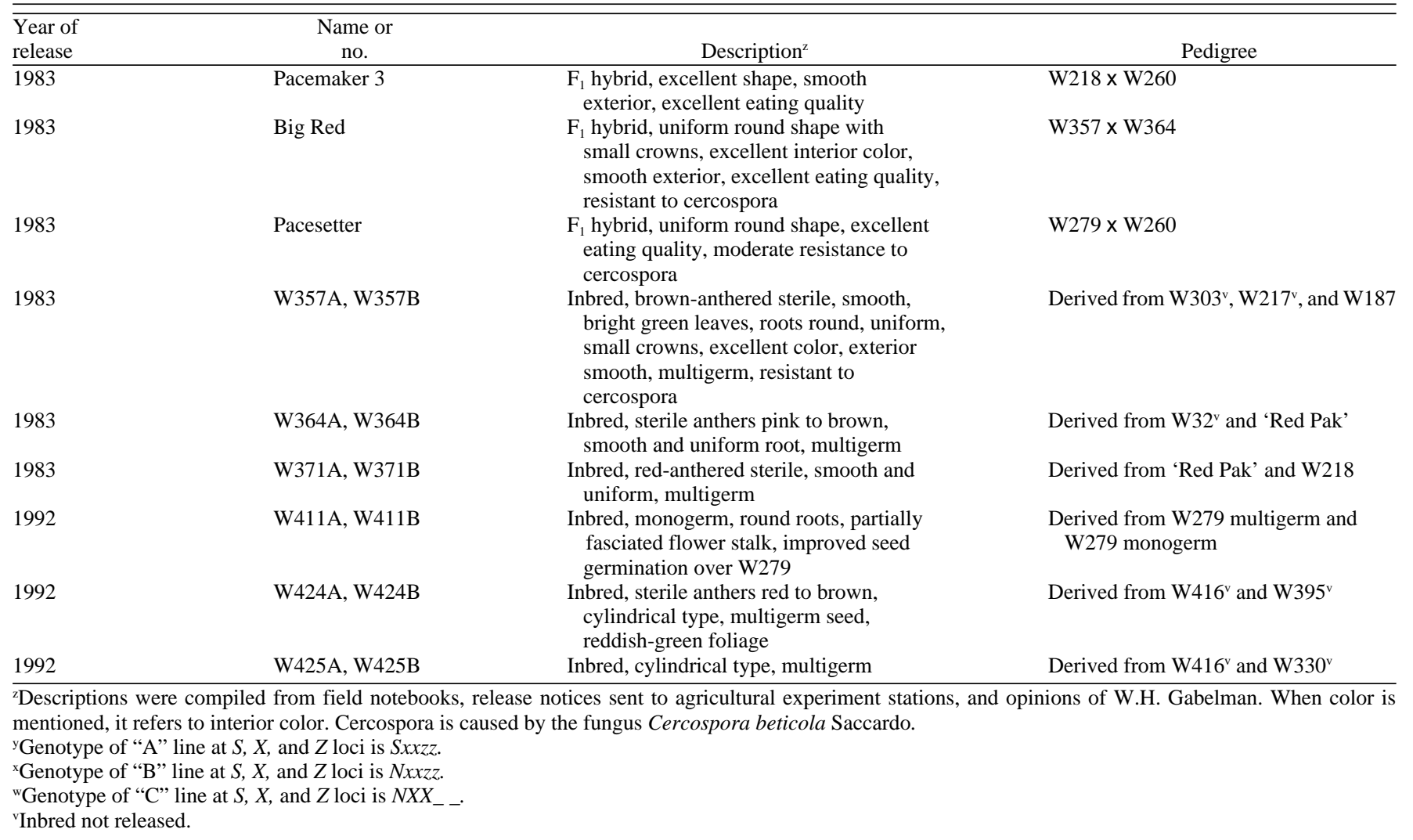

